Article

\title{
Impact of Tillage and Crop Residue Management on the Weed Community and Wheat Yield in a Wheat-Maize Double Cropping System
}

\author{
Jin Zhang ${ }^{1,2} \mathbb{D}$ and Lan-Fang $\mathrm{Wu}^{1, *}$ \\ 1 Key Laboratory of Ecosystem Network Observation and Modeling, Institute of Geographic Sciences and \\ Natural Resources Research, Chinese Academy of Sciences, Beijing 100101, China; zhangj.18b@igsnrr.ac.cn \\ 2 University of Chinese Academy of Sciences, Beijing 100049, China \\ * Correspondence: wulf@igsnrr.ac.cn; Tel.: +86-10-6488-9029
}

\section{check for} updates

Citation: Zhang, J.; Wu, L.-F. Impact of Tillage and Crop Residue Management on the Weed Community and Wheat Yield in a Wheat-Maize Double Cropping System. Agriculture 2021, 11, 265. https://doi.org/10.3390/ agriculture11030265

Academic Editors: Mohsin Tanveer, Mirza Hasanuzzaman and Ejaz Ahmad Khan

Received: 1 March 2021

Accepted: 17 March 2021

Published: 19 March 2021

Publisher's Note: MDPI stays neutral with regard to jurisdictional claims in published maps and institutional affiliations.

Copyright: (c) 2021 by the authors. Licensee MDPI, Basel, Switzerland. This article is an open access article distributed under the terms and conditions of the Creative Commons Attribution (CC BY) license (https:/ / creativecommons.org/licenses/by/ $4.0 /)$.

\begin{abstract}
Weeds are often harmful to crop growth due to the competition for space and resources. A field experiment containing four treatments with three replications in a complete randomized design was conducted at Yucheng Comprehensive Experiment Station, Chinese Academy of Sciences since 2008 to assess the impact of shifting from conventional tillage to no-till with crop residue management on weeds and wheat production at the North China Plain. We found that both aboveground weed density and species richness were higher under continuous no-till (NT) than conventional tillage (CT) in the regrowth and stem elongation stage of wheat growth. On the other hand, aboveground weed density in the stage of flowering and filling decreased with crop residue mulching. The density of the soil seed bank in crop residue removal treatments was significantly higher than that of crop residue retention. Besides, either crop residue mulching or incorporating into the soil significantly increased the wheat yield compared with crop residue removal regardless of tillage management. In conclusion, crop residue retention could decrease the weed density and species richness both aboveground and in the soil seed bank and inhibit the growth of broadleaf weeds by the residue layer. Moreover, crop residue retention could improve the wheat yield.
\end{abstract}

Keywords: weed community; soil seed bank; no-till; crop residue management; wheat yield

\section{Introduction}

Farmland weeds can negatively affect crop production and quality by competing with crops for resources [1,2]. Farmers make great efforts with various weed control strategies to diminish the reduction of yields. However, the current weed control strategies have mainly focused on chemical herbicides, which has led to the quick evolution of herbicide-resistant weeds and serious environmental risks [3-5]. Consequently, alternative methods, such as ecological weed management, should be widely considered [6].

Agronomic practices can affect the weed flora and species composition of the weed community and soil seed bank in arable fields [7]. Crop rotation [8,9], fertilization [10-13], tillage [14-16], and crop residue retention [17-19] are effective measures to control weeds. No-till has been widely accepted in recent decades for many environmental benefits, such as reducing run-off, improving nutrient cycling, reducing soil degradation, decreasing water and soil pollution, and enhancing the activities of soil biota [20]. However, a high infestation of weeds has been recognized as an obstacle in the large-scale adoption of conservation tillage (no-till or reduced tillage) [14,21,22]. Weed controls differ among different tillage systems with small seed species favored by conservation tillage systems for the composition of weed community changes, thus requiring different weed control strategies [23]. Besides, weed emergence often reduces under lower disturbance in conservation tillage systems compared with conventional tillage systems [24]. Therefore, if weeds can be effectively controlled at the beginning years of conservation tillage, the weed 
seed bank will decrease and eventually decrease the potential high infestation of weeds deriving from seeds [25]. Crop residue management is one efficient agronomic practice for weed control that decreases the light reaching the soil surface and gives a comfortable habitat for bacteria, fungi, insects, and other predators [14]. As a consequence, crop residue retention not only decreases field weed density and aboveground biomass $[14,15,26]$, but also keeps the seeds on the soil surface, increasing the chances of being infested by fungi and pathogens [27,28], and provides a favorable environment for predators such as rodents and invertebrates [29]. Some findings have shown that crop residue may release compounds, known as allelochemicals, which act as a restriction for seed germination and seedling growth [30-32].

The North China Plain (NCP) is one of the major cereal production areas of China, covering about $18 \mathrm{M}$ ha, and provides $20 \%$ of the total Chinese food production [33,34]. Conventional farming in the NCP uses intensive tillage, and crop residue is removed or burned. These farming practices cause soil deterioration, unstable crop yields, and some environmental problems [33,35-37]. This study was conducted in a winter wheat (Triticum aestivum L.) field under different tillage and crop residue management since 2008. The initial objective was to examine the effects of tillage and crop residue management on soil physicochemical properties and emissions of greenhouse gases. The aboveground weed community and soil seed bank in the field were never investigated prior to this study. We know little about the impact of conservation tillage and crop residue retention on the weed community structure and composition in a wheatmaize double cropping system, especially in a longterm no herbicide amendment farmland. Therefore, precise investigations are warranted in wheatmaize agroecosystems on the effect of tillage and crop residue management on the weed density, species richness, functional groups, and life forms in both aboveground weed vegetation and soil seed bank. The objectives of this study were to measure the impact of tillage and crop residue management on the aboveground weed community, soil seed bank, and wheat yield in winter wheat.

\section{Materials and Methods}

\subsection{Study Area}

A field experiment was carried out in 2008 at Yucheng Comprehensive Experiment Station $\left(36.57^{\circ} \mathrm{N}, 116.36^{\circ}\right.$ E, elevation $20 \mathrm{~m}$ ) of the Chinese Academy of Sciences in North China, located at Yucheng County, Shandong Province, China. This location has a semiarid climate, with an annual average temperature of $13.4^{\circ} \mathrm{C}$ and $567 \mathrm{~mm}$ annual mean precipitation [38]. The crop rotation was winter wheat (cultivar 'Jimai 22') and summer maize (Zea mays L. cultivar 'Zhengdan 958'). The soil of the experimental field belongs to Calcaric Fluvisol, and the surface soil texture was silt loam (12\% sand, $66 \%$ silt, and $22 \%$ clay) according to the FAO-UNESCO classification system. The soil properties of the study site were shown in Table 1.

Table 1. The physicochemical properties of $0-20 \mathrm{~cm}$ soil at the beginning of the experiment in 2008 [38].

\begin{tabular}{ccccccccc}
\hline $\begin{array}{c}\text { BD } \\
\left(\mathbf{g ~ m}^{-3}\right)\end{array}$ & pH & $\begin{array}{c}\text { SOC } \\
\left(\mathbf{g ~ k g}^{-1}\right)\end{array}$ & $\begin{array}{c}\text { TN } \\
\left(\mathrm{g} \mathrm{kg}^{-1}\right)\end{array}$ & $\begin{array}{c}\text { TP } \\
\left(\mathbf{g ~ k g}^{-1}\right)\end{array}$ & $\begin{array}{c}\text { TK } \\
\left(\mathbf{g ~ k g}^{-1}\right)\end{array}$ & $\begin{array}{c}\text { Av. N } \\
\left(\mathbf{m g ~ k g}^{-1}\right)\end{array}$ & $\begin{array}{c}\text { Av. P } \\
\left(\mathbf{m g ~ k g}^{-1}\right)\end{array}$ & $\begin{array}{c}\text { Av. K } \\
\left(\mathbf{m g ~ k g}^{-1}\right)\end{array}$ \\
\hline 1.31 & 8.13 & 9.23 & 1.11 & 2.43 & 22.10 & 110.47 & 13.19 & 151.95 \\
\hline
\end{tabular}

The abbreviated words BD, SOC, TN, TP, TK, Av. N, Av. P, and Av. K stand for bulk density, soil organic carbon, total $\mathrm{N}$, total $\mathrm{P}$, total $\mathrm{K}$, available $\mathrm{N}$, available $\mathrm{P}$, and available $\mathrm{K}$ respectively.

\subsection{Experimental Design}

The experiment had a complete block design with five treatments and three replicates. Four treatments were selected in this study from five treatments, i.e., (1) conventional tillage with no crop residue (CT-NS), (2) conventional tillage with crop residue (CT-CS), (3) no-till with no crop residue (NT-NS), and (4) no-till with crop residue (NT-CS). The NT treatments (NT-NS, NT-CS) received zero tillage during the whole year, while the CT treatments (CT-NS, CT-CS) were plowed to a 15 to $20 \mathrm{~cm}$ depth using a rotary tiller after the 
maize harvest each year. Wheat was manually harvested with about $10 \mathrm{~cm}$ straw left. Maize was also manually harvested with about $5 \mathrm{~cm}$ straw left and the root pile was manually removed after the maize harvest. Crop residue treatments contained $7000 \mathrm{~kg} \mathrm{ha}^{-1} \mathrm{yr}^{-1}$ of wheat straw and $7500 \mathrm{~kg} \mathrm{ha}^{-1} \mathrm{yr}^{-1}$ of maize residue. Crop residue removal treatment removed all straws and residues after harvest. The wheat straws were not cut into small pieces while the maize residues were cut into nearly 2 to $5 \mathrm{~cm}$ pieces and evenly spread on the soil surface in CT treatments before incorporating into the soil. During the winter wheat season, there were two fertilizer amendments including basal and topdressing fertilizer. The former amendment was applied at a rate of $195 \mathrm{~kg} \mathrm{~N} \mathrm{ha}^{-1}, 45 \mathrm{~kg} \mathrm{P}_{2} \mathrm{O}_{5} \mathrm{ha}^{-1}$, and $60 \mathrm{~kg} \mathrm{~K}_{2} \mathrm{O}$ ha $^{-1}$ with a compound fertilizer $\left(26 \% \mathrm{~N}, 6 \% \mathrm{P}_{2} \mathrm{O}_{5}\right.$, and $\left.8 \% \mathrm{~K}_{2} \mathrm{O}\right)$ during sowing. Topdressing fertilizer of $117 \mathrm{~kg} \mathrm{~N} \mathrm{ha}^{-1}$ was applied with urea $(46 \% \mathrm{~N})$ during the irrigation at the reviving stage of winter wheat at the end of March. No herbicide was applied except manual weeding according to the weed spectrum and expert recommendations during the summer maize season.

\subsection{Soil Collection and Processing}

Soil samples were collected at the beginning of March 2019 before seed germination. The seed bank samples were randomly taken by 20 cylindrical soil cores $(1.8 \mathrm{~cm}$ diameter $)$ in each plot. The soil cores were separated into four layers (i.e., 0 to $5 \mathrm{~cm}, 5$ to $10 \mathrm{~cm}, 10$ to $15 \mathrm{~cm}, 15$ to $20 \mathrm{~cm}$ ). The 20 soil cores from each soil layer were mixed per plot. Soil samples were placed on a table in front of a north-facing window for 10 days direct exposure and were sieved through a coarse $(4.0 \mathrm{~mm}$ mesh width) and fine sieve $(0.2 \mathrm{~mm}$ mesh width) to remove both stones, plant fragments, and fine soil materials [39]. Soil samples were then chilled in a $5^{\circ} \mathrm{C}$ refrigerator until processing to break seed dormancy [40].

\subsection{Seed Bank Determination}

The direct germination method was used to access the germinable seeds [7,41]. Soil samples were spread in a thin layer $(<1 \mathrm{~cm})$ on a 4 -cm-deep soil layer (sterilized at $140{ }^{\circ} \mathrm{C}$ for $24 \mathrm{~h}$ ) in a $54 \times 28 \times 5 \mathrm{~cm}$ plastic tray divided into equal thirds. Samples were randomly assigned to each third of the tray, with "no samples added" controls included as a treatment [42]. Trays were placed in an unheated greenhouse for more than 10 weeks. All trays were watered regularly to keep the soil sample moist. Seedlings were identified and removed from the trays as soon as possible $[43,44]$. Any seedlings that can not be identified were replanted to another tray until they could be identified. Soil samples were carefully stirred following the cessation of the initial flush of germinatiom to facilitate the emergence of new seedlings. [45,46] Since no additional seeds germinated for two weeks, the experiment was terminated. The seedling number is used to calculate the seed density of seed bank per $\mathrm{m}^{2}$ [44].

\subsection{Weed Sampling}

Weed evaluations were conducted from March to June 2019. At the weed survey, four $0.25 \mathrm{~m}^{2}(0.5 \mathrm{~m} \times 0.5 \mathrm{~m})$ quadrats were away from the alley and randomly distributed in each plot to limit edge effects. Weed species were identified and their density was visually assessed. At the end of the grain filling, all weeds presented in each quadrat were clipped at ground level, sorted to species, counted, and oven-dried at $70^{\circ} \mathrm{C}$ for $48 \mathrm{~h}$ before weighing. The wheat yield was measured after harvest.

The floristic structure was analyzed in terms of the species composition, and the functional structure was analyzed in terms of the morphological types (i.e., monocotyledonous and dicotyledonous) and life cycle (i.e., annual and perennial).

\subsection{Statistical Analysis}

The weed density was counted as the total plants of all the weed species per square meter. The species richness in each plot was defined as the total number of species detected in the four quadrats. The weed densities were log-transformed prior to analyses to meet 
the homogeneity of variance assumptions. The BergerParker dominance index $(d)$ was calculated as $d=N \max / N$, where Nmax is the plant density of certain dominant species and $N$ is total plant species. Data were analyzed using analysis of variance (ANOVA), and means were compared based on Tukey's multiple comparison tests at the 0.05 probability level. All statistical analyses were carried out with SPSS 20.0 (SPSS Inc., Chicago, IL, USA), and all plots were conducted with SigmaPlot 12.5 (Systat Software Inc., San Jose, CA, USA).

\section{Results}

\subsection{Species Richness in Aboveground Vegetation and Soil Seed Bank}

Twenty-one weed species from 14 families were recorded in aboveground vegetation of which there were nine annuals and 12 perennials (Table S1). The species richness increased before the flowering stage and then decreased during our observation period (Figure 1a). No-till treatments (NT-NS, NT-CS) showed more species richness than conventional tillage treatments (CT-NS, CT-CS) at the reviving and elongation stage, while the weed species richness in crop residue retention treatments (CT-CS, NT-CS) was lower during the later period (flowering and filling stage). The results showed weed species richness in aboveground vegetation varied by the stage, tillage, and straw retention $(p<0.05)$, but was unaffected by its interaction with these factors (Table S4). A total of 615 seedlings of 22 species from 15 families emerged from the soil seed bank, of which there were 15 annuals and seven perennials (Table S2). The soil seed bank was dominated by Digitaria sanguinalis (L.) Scop. and Portulaca oleracea L. (Table S3), and these two species accounted for more than $68 \%$ of the seedlings. Eight species contributed $26 \%$ of all seedlings and the other 12 species accounted for only $5 \%$. The weed species richness in the soil seed bank was affected by the soil depth and its interaction with tillage $(p<0.01)$ (Figure 1b, Table S5). Eleven species were present in both aboveground vegetation and the soil seed bank.
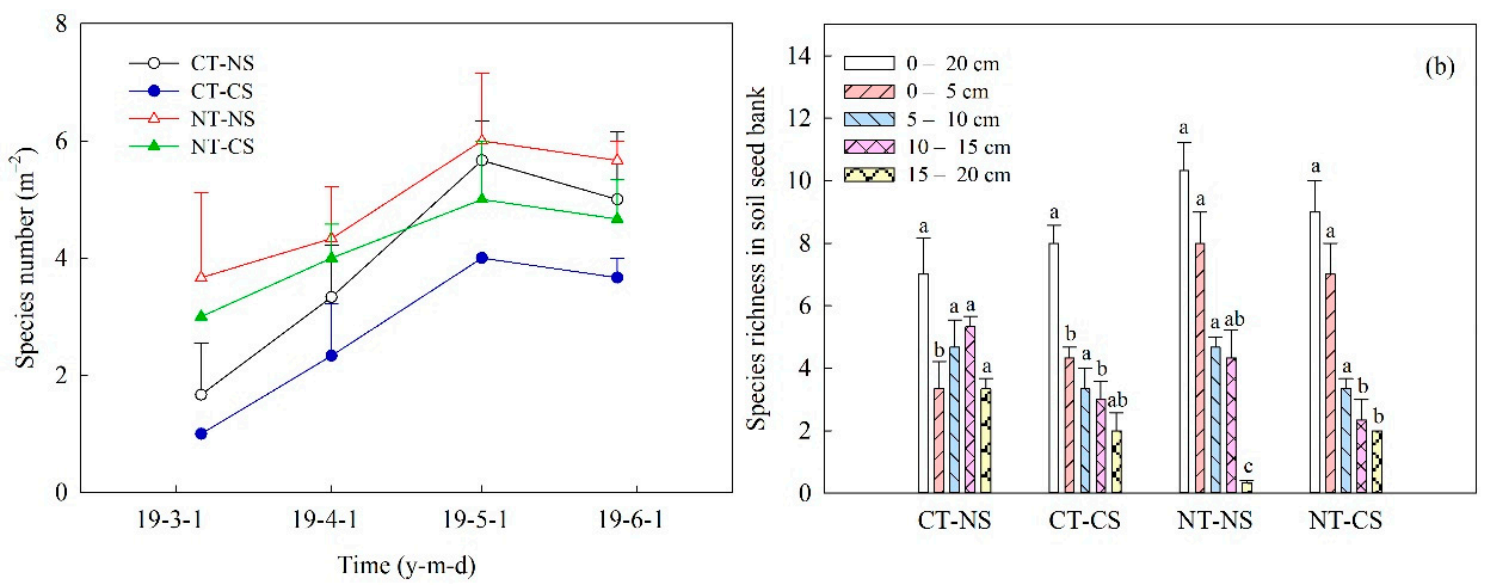

Figure 1. Species richness in vegetation (a) and soil seed bank (b) under conventional tillage with no crop residue (CT-NS), conventional tillage with crop residue (CT-CS), no-till with no crop residue (NT-NS), and no-till with crop residue (NT-CS). Different letters indicate significant difference among treatments (one-way ANOVA, $p<0.05$ ). Bars represent means $\pm \mathrm{SE}$.

\subsection{Weed Density in Aboveground Vegetation and Seed Density in the Soil Seed Bank}

The aboveground weed density in no-till treatments was higher than conventional tillage treatments before the period of flowering (Figure 2a). The weed density in CS treatments increased before the flowering stage and decreased in the later stages while the NS treatments showed a continuous increase during the wheat growing period. Aboveground, the weed density varied by the stage, tillage, straw retention, and the interaction of tillage and straw $(p<0.05)$ (Table S4). The weed density in the soil seed bank was affected by soil depth, straw, and the interaction of soil depth and other factors $(p<0.01)$ (Table S5). Soil seeds at 0 to $5 \mathrm{~cm}$ accounted for $77 \%$ and $54 \%$ of the total soil seed bank density in 
NT-NS and NT-CS treatments, respectively. Soil seeds in conventional tillage treatments were evenly distributed in each soil layer (Figure $2 b$ ).
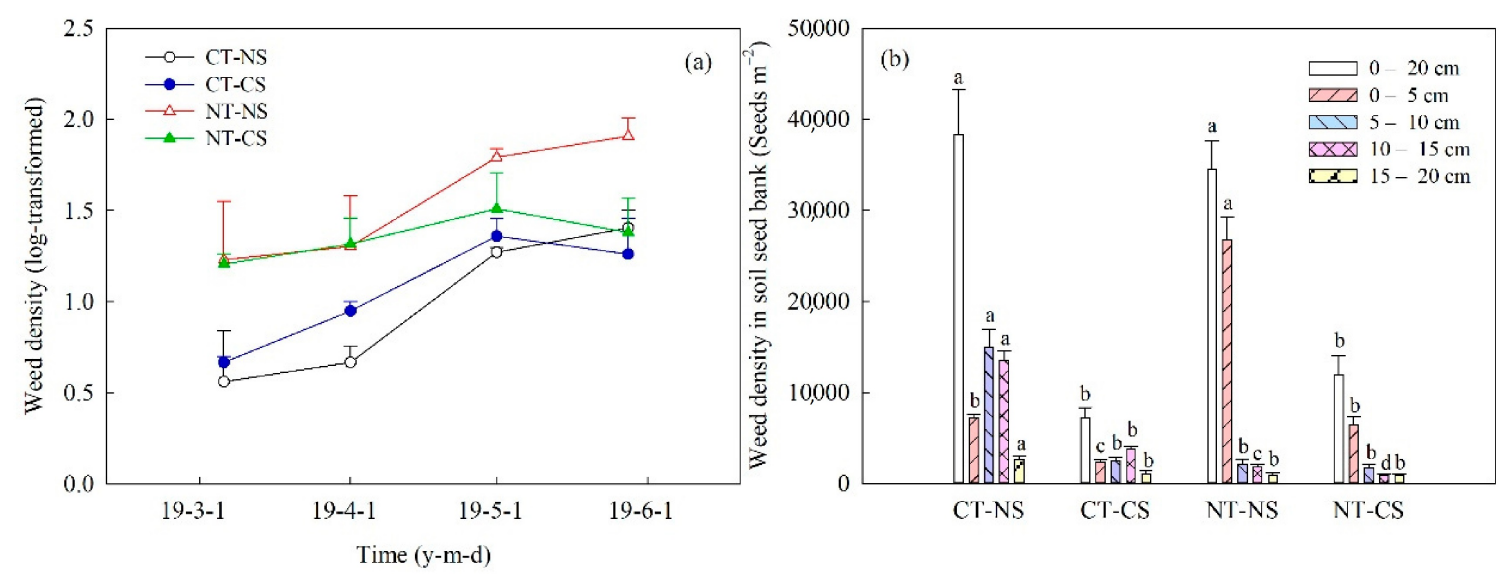

Figure 2. Weed density in vegetation (a) and soil seed bank (b) under conventional tillage with no crop residue (CT-NS), conventional tillage with crop residue (CT-CS), no-till with no crop residue (NT-NS), and no-till with crop residue (NT-CS). Different letters indicate significant difference among treatments (one-way ANOVA, $p<0.05$ ). Bars represent means \pm SE.

\subsection{Functional Groups in Aboveground Vegetation and Soil Seed Bank}

Dicotyledonous weed was the dominant functional group in CT-NS, CT-CS, and NTNS treatments while monocotyledonous weed was dominant in NT-CS in aboveground vegetation (Figure 3a). The proportion of monocotyledonous and dicotyledonous weeds in the seed bank differed among different treatments (Figure 3b). The proportion of monocotyledonous weed in the soil seed bank was under the following order: NT-NS $>$ CTNS $>$ CT-CS $>$ NT-CS. The relative proportion of the functional group (monocotyledonous and dicotyledonous) varied significantly with straw retention treatment $(p<0.05)$ (Table S6).
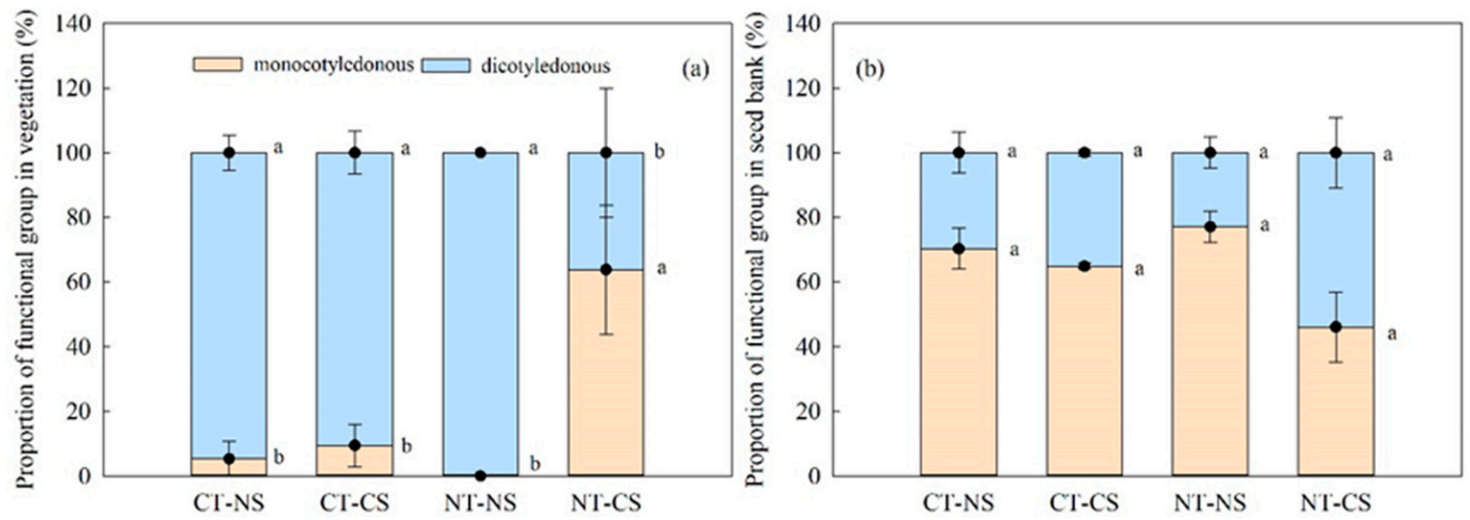

Figure 3. The proportion of functional group in vegetation (a) and soil seed bank (b) under conventional tillage with no crop residue (CT-NS), conventional tillage with crop residue (CT-CS), no-till with no crop residue (NT-NS), and no-till with crop residue (NT-CS). Different letters indicate significant difference among treatments (one-way ANOVA, $p<0.05$ ). Bars represent means $\pm \mathrm{SE}$.

\subsection{Life Forms in Aboveground Vegetation and Soil Seed Bank}

The proportion of annuals in the aboveground vegetation was under the following order: NT-CS > CT-CS > NT-NS > CT-CS (Figure 4a). In the soil seed bank, the proportion of perennial weeds was less than $20 \%$ under all treatments (Figure $4 \mathrm{~b}$ ). The relative proportion of the life form (annuals and perennials) in the soil seed bank varied with tillage treatment $(p<0.01)$ (Table S6). 

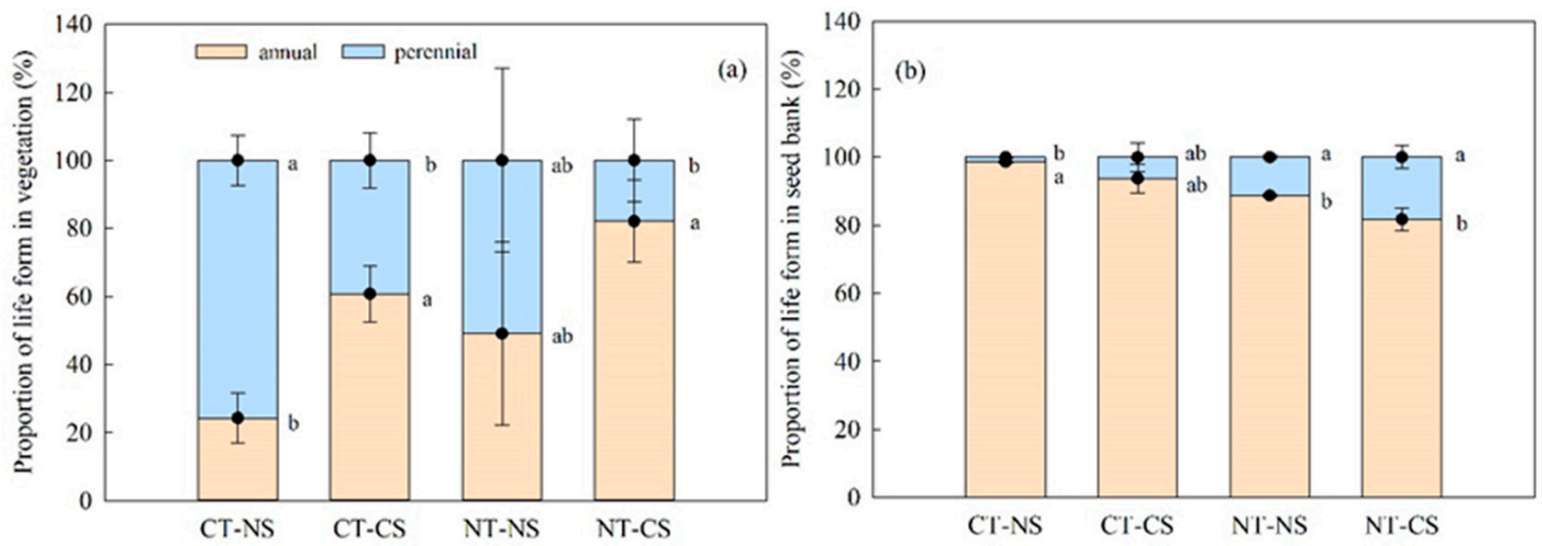

Figure 4. The proportion of life form in vegetation (a) and soil seed bank (b) under conventional tillage with no crop residue (CT-NS), conventional tillage with crop residue (CT-CS), no-till with no crop residue (NT-NS), and no-till with crop residue (NT-CS). Different letters indicate significant difference among treatments (one-way ANOVA, $p<0.05$ ). Bars represent means \pm SE.

\subsection{Aboveground Biomass of Weeds}

The total aboveground weed biomass of this study followed the order: NT-CS > NTNS > CT-NS > CT-CS (Figure 5). CT-CS showed significantly lower aboveground weed biomass than other treatments $(p<0.05)$. The aboveground biomass of dicotyledonous weeds in NS treatments accounted for more than $96 \%$ of the total weed aboveground biomass. NT-CS showed the highest monocotyledonous weed biomass (more than $86 \%$ of the total weed biomass), which was significantly higher than other treatments $(p<0.05)$.

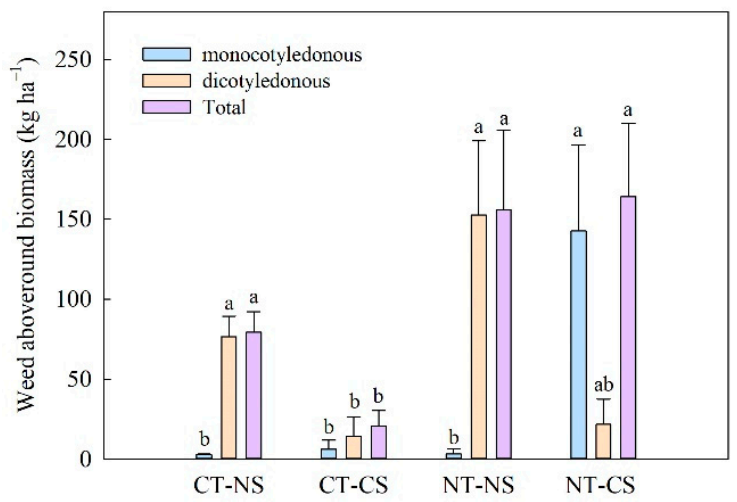

Figure 5. The aboveground weed biomass before wheat harvesting under conventional tillage with no crop residue (CT-NS), conventional tillage with crop residue (CT-CS), no-till with no crop residue (NT-NS), and no-till with crop residue (NT-CS). Different letters indicate significant difference among treatments (one-way ANOVA, $p<0.05$ ). Bars represent means $\pm \mathrm{SE}$.

\subsection{Wheat Yield}

The wheat yield of this study followed the order: NT-CS $>$ CT-CS $>$ CT-NS $>$ NT-NS (Table 2). NT-CS and CT-CS showed significantly higher wheat yield than that of CT-NS and NT-NS $(p<0.05)$. No significant differences were found between NT-CS and CT-CS treatments, as well as CT-NS and NT-NS treatments $(p>0.05)$. The 1000 grain weight was significantly higher in NT-CS treatment than that of CT-NS and CT-CS treatments $(p<0.05)$. The highest number of spikes per square meter was in NT-CS, followed by CT-CS, and CT-NS and NT-NS showed lower spike numbers than that of NT-CS and CT-CS $(p<0.05)$. No difference in grain weight per spike was observed under all the treatments $(p>0.05)$. The wheat yield was not significantly affected by the aboveground biomass of monocotyledonous weeds, while a negative correlation was observed between 
the aboveground biomass of broadleaf weeds and crop yield $\left(r^{2}=0.5120, p=0.0026\right)$, indicating that the increase of the broadleaf weed biomass was one of the main causes of the reduction in crop yield (Figure 6).

Table 2. Grain yield of winter wheat and its components under different treatments.

\begin{tabular}{ccccc}
\hline Treatment & $\begin{array}{c}\text { Grain Yield } \\
\mathbf{( k g ~ h a}^{-1} \mathbf{)}\end{array}$ & $\begin{array}{c}\text { 1000 Grain } \\
\text { Weight } \mathbf{( g )}\end{array}$ & $\begin{array}{c}\text { Spike Number } \\
\mathbf{( m}^{-\mathbf{2}} \mathbf{)}\end{array}$ & $\begin{array}{c}\text { Grain Weight } \\
\text { per Spike (g) }\end{array}$ \\
\hline CT-NS & $5570 \pm 70 \mathrm{~b}$ & $39.68 \pm 0.48 \mathrm{~b}$ & $390.67 \pm 18.81 \mathrm{c}$ & $1.44 \pm 0.13 \mathrm{a}$ \\
CT-CS & $6370 \pm 190 \mathrm{a}$ & $40.38 \pm 0.39 \mathrm{~b}$ & $478.67 \pm 23.13 \mathrm{~b}$ & $1.08 \pm 0.08 \mathrm{a}$ \\
NT-NS & $5280 \pm 210 \mathrm{~b}$ & $40.51 \pm 0.63 \mathrm{ab}$ & $349.33 \pm 39.75 \mathrm{c}$ & $1.30 \pm 0.05 \mathrm{a}$ \\
NT-CS & $6750 \pm 120 \mathrm{a}$ & $43.41 \pm 0.18 \mathrm{a}$ & $521.33 \pm 29.33 \mathrm{a}$ & $1.27 \pm 0.01 \mathrm{a}$ \\
\hline
\end{tabular}

Values are means \pm SE $(n=3)$. Different letters indicate a significant difference between the treatments (one-way ANOVA, $p<0.05)$. CT-NS: conventional tillage with no crop residue, CT-CS: conventional tillage with crop residue, NT-NS: no-till with no crop residue, NT-CS: no-till with crop residue.

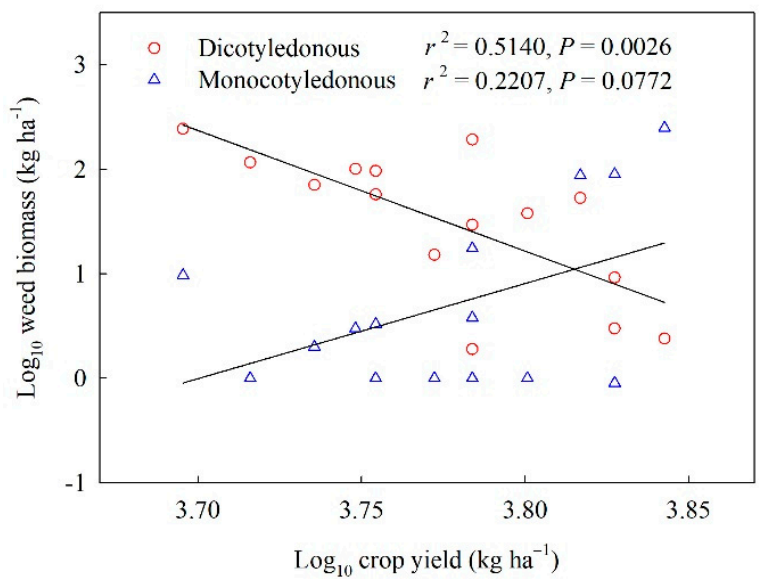

Figure 6. Correlation between crop yield and the aboveground biomass of dicotyledonous weeds and monocotyledonous weeds.

\section{Discussion}

\subsection{Impact of Tillage and Crop Residue Management on Weed Species Richness and Weed Density}

This study indicated that tillage was an effective measure to suppress the weed occurrence, especially in the early stages of wheat growth (Figures 1a and 2a), being consistent with previous researchers $[14,47]$. These findings could be primarily attributed to the disturbance of tillage burying weed seeds in the deep soil layer, decreasing the emergence of seedlings deriving from seeds [47]. The site managed by crop residue retention (CT-CS, NT-CS) showed a relatively lower weed species richness than that of no crop residue treatments (CT-NS, NT-NS) after the flowering stage (Figure 1a), which was similar to the result of other studies [48]. This can be explained by the fact that crop residues changed the physicochemical environment of seed emergence [48]. For example, the crop residue layer on the soil surface blocks light, becoming a barrier for the seed germination of many weed species [49]. The highest species richness was revealed in the flowering stage (early May), which suggests the best observation time of the weed composition is the flowering stage. Weeds may be effectively controlled if the weed seedlings can be removed in the early stages of winter wheat. The present study found soil seed density in crop residue removal treatments was significantly higher than that of residue retention treatments (Figure $2 b$ ). This could be due to the fact that the crop residues can retain weed seeds on the soil surface and shallow soil layer, increasing the seed depletion rate by the infection of fungi and pathogens and the predation of weed seed predators [27-29]. No-till treatments showed an accumulation of weed seeds in the top five centimeters of the soil (Figure 2b), indicating tillage management could alter the composition and distribution of seed bank [50]. Although most research related to soil seed banks have used the direct 
germination seedbank method, there is the inevitable problem of viable but dormant seeds that do not germinate during the period of the germination despite efforts to provide appropriate environmental conditions for breaking dormancy and germination. Future studies of soil seed banks should be evaluated by both the germination seedbank method and the extractable seedbank method, if possible.

Interestingly, the result of the present study showed that the aboveground weed density was decreased after the flowering stage in crop residue retention treatments, while it consistently increased in the no crop residue treatments (Figure 2a). This finding could be primarily attributed to the sensitivity of weed seedlings to the environment (i.e., soil moisture, soil temperature, soil $\mathrm{pH}$, and allelochemicals) caused by the remaining crop residues [51-54]. The biomass of crop residue also plays an essential role in weed controlling. No impact was observed in total dry weed biomass at seven days after planting with the crop residue of an average dry weight of $2340 \mathrm{~kg} \mathrm{ha}^{-1}$ of hairy vetch [17]. However, when the dry weight of hairy vetch was up to $6000 \mathrm{~kg} \mathrm{ha}^{-1}$, the weed density was effectively controlled [55]. Successful weed control by mulches was highly dependent on sufficient biomass [26]. With the degradation of crop residue over time, annually supplementary stubble was necessary for weed control when the biomass was not sufficient. However, researches into the biochemical seed defense responses and the relative enzymes employed by soil fungi in their attack of weed seeds in the straw retention farmland soil are extremely sparse.

\subsection{Effects of Tillage and Crop Residue Management on Functional Group of Weeds}

The dominant functional group in CT-NS, CT-CS, and NT-NS treatments was the dicotyledonous weed group in aboveground vegetation while monocotyledonous weeds were dominant in these three treatments in the soil seed bank (Figure 3). This finding can be primarily attributed to the cooler average soil temperature and less drastic fluctuations in the wheat growing season, leading to a delay in seed germination $[49,56]$. The proportion of dicotyledonous weeds in the present study was higher in crop residue retention than that of crop residue removal treatments in the soil seed bank (Figure 3b). Cover crop residue would provide a physical barrier for a seedling to penetrate before it exhausted its energy reserves [49], which may favor larger seeds of perennials and impede graminoid survival.

This study demonstrated an interesting result that the biomass of graminoid weeds under NT-CS accounted for more than $85 \%$ of the total weed biomass, while other treatments accounted for less than one-third of the total weed biomass (Figure 5). The dissimilarity of the total weed biomass and its proportion may be attributed to the tillage and crop residue management, resulting in the difference in light, temperature, moisture, and property of soil between treatments, thereby affecting weed emergence and the aboveground biomass. The significantly higher aboveground dry matter of graminoids in NT-CS than other treatments could be due to the higher soil water content and less soil disturbance under no-till with crop residue conditions. These findings suggest that the broadleaf weeds (forbs and legumes) may be resistant to drought due to different root systems $[57,58]$. The graminoids belong to the shallower- and fibrous-rooted species, whereas other weeds showed a taproot [59]. The shallower and fibrous roots of graminoid weeds may limit their ability to utilize deeper soil water, while the taproot forbs can obtain water from much deeper soil layers, which helps their survival in drought conditions $[60,61]$. Therefore, the difference of functional groups among treatments suggested that tillage and crop residue management affected field micro-climate, such as soil disturbance and water content, changing the weed composition and diversity.

\subsection{Effects of Tillage and Crop Residue Management on Life Forms of Weeds}

This study found that no-till treatments favored the proportion of perennial weeds in the soil seed bank (Figure $4 \mathrm{~b}$ ), which is consistent with other studies [62], showing that reducing tillage typically results in a shift from annual to perennial weeds. Besides, the present study showed more proportion of perennials in crop residue removal treatments, 
which is in contrast to other studies [55,63]. Generally, cover crops or other mulches are better at suppressing small seed summer annuals and are ineffective at suppressing perennial weeds [62]. Crop residues must be present in high amounts to provide the suppression of annual weeds, whereas the low amount of crop residue can stimulate weed emergence $[55,63]$.

\subsection{Effects of Tillage and Crop Residue Management on Crop Yield}

It is generally accepted that crop yields are affected by agronomic practices. Conventional tillage tends to reduce the soil bulk density and macro-aggregates [64-66], and decreases soil organic carbon [66], affecting MBC: SOC ratio, MBC: MBN ratio, and C: N ratio [38], leading to lower water and nutrient utilization efficiency. Consequently, crop yields become unstable and unpredictable. Many studies have shown long-term NT management enhanced crop yields [33,67]. However, other researchers found that crop yield under NT management decreased, was unchanged, or only increased in the beginning years $[68,69]$. The results of this study found no significant differences in wheat yields and their components between CT treatments and NT treatments (Table 2). However, the present study found crop residue retention treatments had higher wheat yields than that of crop residue removals, suggesting that field mulching with crop residue promotes crop yield. This could be attributed to the residues and their decomposition improving the soil structure through enhancing the soil aggregate stability and soil properties while limiting soil water evaporation and soil crusting [70]. The improved soil property increased its water infiltration and water availability to the crop [71-73], which enhances the wheat growth and yield. Additionally, mulching with crop residues impacts the weed emergence and biomass, so that the competition between weeds and the crop could be mitigated and the crop yield may increase [49,52]. Although the dry matter of weeds was significantly higher in NT-CS than that of CT-CS, the NT-CS had a higher crop yield than CT-CS. This could be attributed, firstly, to the yield benefits gained from no-till and the crop residue layer on the ground, which are mainly linked to its favorable environmental and soil conditions compared with conventional tillage. Secondly, NT-CS had a lower percentage of broadleaf weed biomass than CT-CS (Figure 5). The lower presence of broadleaf weeds, which competed with wheat for resources, especially light and space in the early stage, increased the crop yield in NT-CS, more so than that of CT-CS.

\section{Conclusions}

This study supports a growing body of evidence that aboveground weed species richness and weed density increased first and then decreased during the winter wheat growth period. Tillage interfered with the rhizome propagation of perennial weeds. Crop residue retention decreased the soil weed bank $(0$ to $20 \mathrm{~cm})$ and aboveground biomass of dicotyledonous weeds, and profited wheat yield. A weed control strategy was proposed in the wheat-maize double cropping system through approaches such as the timely removal of surface weeds in the early stage of wheat growth based on tillage and straw retention management. The flexible use of weeding methods can not only reduce weed damage but also increase the crop yield. Our findings might provide a theoretical basis for weed management in organic farming systems.

Supplementary Materials: The following are available online at https: / www.mdpi.com/2077-0 472/11/3/265/s1, Table S1: Aboveground weed species under different treatments in the winter wheat field in NCP., Table S2: Seed bank under different treatments in the winter wheat field in NCP., Table S3: Berger-Parker dominance index $(d)$ of soil seed bank under different treatments in the winter wheat field in NCP., Table S4: Analysis of variance (F-statistics and $p$-values) for weed species richness and weed density in aboveground vegetation during the period of study. Stages were the growth stages of winter-wheat., Table S5: Analysis of variance ( $F$-statistics and $p$-values) for weed species richness and weed density in the soil seed bank. Depths were 0 to $5 \mathrm{~cm}, 5$ to $10 \mathrm{~cm}, 10$ to $15 \mathrm{~cm}$, and 15 to $20 \mathrm{~cm}$., Table S6: Analysis of variance (F-values) for weed functional group and life form in aboveground vegetation and soil seed bank. Raw data: The data presented in this study. 
Author Contributions: J.Z.: conceptualization, methodology, software, validation, formal analysis, investigation, resources, data curation, visualization, and writing-original draft preparation. L.-F.W.: conceptualization, validation, resources, writing-review and editing, supervision, project administration, and funding acquisition. All authors have read and agreed to the published version of the manuscript.

Funding: This research was funded by the National Key Research and Development Program in China, grant number 2019YFD1002703 \& 2013BAD05B03.

Institutional Review Board Statement: Not applicable.

Informed Consent Statement: Not applicable.

Data Availability Statement: The data presented in this study are available in a supplementary material.

Acknowledgments: We are very grateful to Ruojing Wang from the Seed Science and Technology Section, Saskatoon Laboratory, the Canadian Food Inspection Agency for valuable comments. We also thank the staff members at Yucheng Comprehensive Experiment Station, CAS, for supporting the fieldwork.

Conflicts of Interest: The authors declare no conflict of interest.

$\begin{array}{ll}\text { Abbreviations } \\ \text { NCP } & \text { The North China Plain } \\ \text { CT } & \text { Conventional tillage } \\ \text { NT } & \text { No-till } \\ \text { NS } & \text { No crop residue retention } \\ \text { CS } & \text { Crop residue retention } \\ \text { CT-NS } & \text { Conventional tillage without crop residue retention } \\ \text { CT-CS } & \text { Conventional tillage with crop residue retention } \\ \text { NT-NS } & \text { No-till without crop residue retention } \\ \text { NT-CS } & \text { No-till with crop residue retention }\end{array}$

\section{References}

1. Soltani, N.; Dille, J.A.; Robinson, D.E.; Sprague, C.L.; Morishita, D.W.; Lawrence, N.C.; Kniss, A.R.; Jha, P.; Felix, J.; Nurse, R.E.; et al. Potential yield loss in sugar beet due to weed interference in the United States and Canada. Weed Technol. 2018, 32, 749-753. [CrossRef]

2. Vollmann, J.; Wagentristl, H.; Hartl, W. The effects of simulated weed pressure on early maturity soybeans. Eur. J. Agron. 2010, 32, 243-248. [CrossRef]

3. Annett, R.; Habibi, H.R.; Hontela, A. Impact of glyphosate and glyphosate-based herbicides on the freshwater environment. J. Appl. Toxicol. 2014, 34, 458-479. [CrossRef]

4. Dalton, R.L.; Boutin, C. Comparison of the effects of glyphosate and atrazine herbicides on nontarget plants grown singly and in microcosms. Env. Toxicol. Chem. 2010, 29, 2304-2315. [CrossRef]

5. Gu, X.; Cen, Y.; Guo, L.; Li, C.; Yuan, H.; Xu, Z.; Jiang, G. Responses of weed community, soil nutrients, and microbes to different weed management practices in a fallow field in Northern China. Peerj 2019, 7, e7650. [CrossRef] [PubMed]

6. Halde, C.; Bamford, K.C.; Entz, M.H. Crop agronomic performance under a six-year continuous organic no-till system and other tilled and conventionally-managed systems in the northern Great Plains of Canada. Agricecosyst Environ. 2015, 213, 121-130. [CrossRef]

7. Fracchiolla, M.; Stellacci, A.M.; Cazzato, E.; Tedone, L.; Alhajj Ali, S.; De Mastro, G. Effects of conservative tillage and nitrogen management on weed seed bank after a seven-year durum wheat-faba bean rotation. Plants 2018, 7, 82. [CrossRef]

8. Sarani, M.; Oveisi, M.; Mashhadi, H.R.; Alizade, H.; Gonzalez-Andujar, J.L. Interactions between the tillage system and crop rotation on the crop yield and weed populations under arid conditions. Weed Biol Manag. 2014, 14, 198-208. [CrossRef]

9. Muminov, M.A.; Guo, L.; Song, Y.; Gu, X.; Cen, Y.; Meng, J.; Jiang, G. Comparisons of weed community, soil health and economic performance between wheat-maize and garlic-soybean rotation systems under different weed managements. PeerJ 2018, 6, e4799. [CrossRef]

10. Mohler, C.L.; Caldwell, B.A.; Marschner, C.A.; Cordeau, S.; Maqsood, Q.; Ryan, M.R.; DiTommaso, A. Weed seedbank and weed biomass dynamics in a long-term organic vegetable cropping systems experiment. Weed Sci. 2018, 66, 611-626. [CrossRef]

11. Tang, L.; Wan, K.; Cheng, C.; Li, R.; Wang, D.; Pan, J.; Tao, Y.; Xie, J.; Chen, F. Effect of fertilization patterns on the assemblage of weed communities in an upland winter wheat field. J. Plant Ecol. 2013, 7,39-50. [CrossRef] 
12. Yin, L.; Cai, Z.; Zhong, W. Changes in weed community diversity of maize crops due to long-term fertilization. Crop Protect. 2006, 25, 910-914. [CrossRef]

13. Major, J.; Steiner, C.; Ditommaso, A.; Falcao, N.P.S.; Lehmann, J. Weed composition and cover after three years of soil fertility management in the central Brazilian Amazon: Compost, fertilizer, manure and charcoal applications. Weed Biol Manag. 2005, 5, 69-76. [CrossRef]

14. Yang, M.; Zhao, Y.; Yang, H.; Shen, Y.; Zhang, X. Suppression of weeds and weed seeds in the soil by stubbles and no-tillage in an arid maize-winter wheat-common vetch rotation on the Loess Plateau of China. J. Arid Land. 2018, 10, 809-820. [CrossRef]

15. Campiglia, E.; Radicetti, E.; Mancinelli, R. Weed control strategies and yield response in a pepper crop (Capsicum annuum L.) mulched with hairy vetch (Vicia villosa Roth.) and oat (Avena sativa L.) residues. Crop Protect. 2012, 33, 65-73. [CrossRef]

16. Baghel, J.K.; Das, T.K.; Pankaj; Mukherjee, I.; Nath, C.P.; Bhattacharyya, R.; Ghosh, S.; Raj, R. Impacts of conservation agriculture and herbicides on weeds, nematodes, herbicide residue and productivity in direct-seeded rice. Soil Tillage Res. 2020, $201,104634$. [CrossRef]

17. Koger, C.H.; Reddy, K.N. Effects of hairy vetch (Vicia villosa) cover crop and banded herbicides on weeds, grain yield, and economic returns in corn (Zea mays). J. Sustain. Agric. 2005, 26, 107-124. [CrossRef]

18. Haramoto, E.R.; Pearce, R. Cover crop termination treatment impacts weed suppression potential. Weed Sci. 2019, 67, 91-102. [CrossRef]

19. Price, A.J.; Korres, N.E.; Norsworthy, J.K.; Li, S. Influence of a cereal rye cover crop and conservation tillage on the critical period for weed control in cotton. Weed Technol. 2018, 32, 683-690. [CrossRef]

20. Holland, J.M. The environmental consequences of adopting conservation tillage in Europe: Reviewing the evidence. Agricecosyst. Environ. 2004, 103, 1-25. [CrossRef]

21. Buhler, D.D.; Stoltenberg, D.E.; Becker, R.L.; Gunsolus, J.L. Perennial weed populations after 14 years of variable tillage and cropping practices. Weed Sci. 1994, 42, 205-209. [CrossRef]

22. San Martin, C.; Long, D.S.; Gourlie, J.A.; Barroso, J. Weed responses to fallow management in Pacific Northwest dryland cropping systems. PLoS ONE 2018, 13, e0204200. [CrossRef]

23. Chauhan, B.S.; Gill, G.; Preston, C. Seedling recruitment pattern and depth of recruitment of 10 weed species in minimum tillage and no-till seeding systems. Weed Sci. 2006, 54, 658-668. [CrossRef]

24. Chauhan, B.S.; Gill, G.S.; Preston, C. Effect of seeding systems and dinitroaniline herbicides on emergence and control of rigid ryegrass (Lolium Rigidum) in wheat. Weed Technol. 2007, 21, 53-58. [CrossRef]

25. Farooq, M.; Flower, K.C.; Jabran, K.; Wahid, A.; Siddique, K.H.M. Crop yield and weed management in rainfed conservation agriculture. Soil Tillage Res. 2011, 117, 172-183. [CrossRef]

26. Reberg-Horton, S.C.; Grossman, J.M.; Kornecki, T.S.; Meijer, A.D.; Price, A.J.; Place, G.T.; Webster, T.M. Utilizing cover crop mulches to reduce tillage in organic systems in the southeastern USA. Renew. Agric. Food Syst. 2011, 27, 41-48. [CrossRef]

27. Kulkarni, S.S.; Dosdall, L.M.; Willenborg, C.J. The role of ground beetles (coleoptera: Carabidae) in weed seed consumption: A review. Weed Sci. 2017, 63, 355-376. [CrossRef]

28. Bohan, D.A.; Boursault, A.; Brooks, D.R.; Petit, S. National-scale regulation of the weed seedbank by carabid predators. J. Appl. Ecol. 2011, 48, 888-898. [CrossRef]

29. Gallandt, E.R. How can we target the weed seedbank? Weed Sci. 2006, 54, 588-596. [CrossRef]

30. Putnam, A.R.; Defrank, J. Use of phytotoxic plant residues for selective weed-control. Crop Protect. 1983, 2, 173-181. [CrossRef]

31. Duke, S.O. Proving allelopathy in crop-weed interactions. Weed Sci. 2015, 63, 121-132. [CrossRef]

32. Duke, S.O. Allelopathy: Current status of research and future of the discipline: A commentary. Allelopath. J. 2010, 25, 17-30.

33. He, J.; Li, H.; Rasaily, R.G.; Wang, Q.; Cai, G.; Su, Y.; Qiao, X.; Liu, L. Soil properties and crop yields after 11 years of no tillage farming in wheat-maize cropping system in North China Plain. Soil Tillage Res. 2011, 113, 48-54. [CrossRef]

34. Sun, H.; Zhang, X.; Chen, S.; Pei, D.; Liu, C. Effects of harvest and sowing time on the performance of the rotation of winter wheat-summer maize in the North China Plain. Ind. Crop. Prod. 2007, 25, 239-247. [CrossRef]

35. Peigné, J.; Vian, J.-F.; Payet, V.; Saby, N.P.A. Soil fertility after 10 years of conservation tillage in organic farming. Soil Tillage Res. 2018, 175, 194-204. [CrossRef]

36. Mwango, S.B.; Msanya, B.M.; Mtakwa, P.W.; Kimaro, D.N.; Deckers, J.; Poesen, J. Effectiveness of mulching under Miraba in controlling soil erosion, fertility restoration and crop yield in the Usambara Mountains, Tanzania. Land Degrad. Dev. 2016, 27, 1266-1275. [CrossRef]

37. Cookson, W.R.; Murphy, D.V.; Roper, M.M. Characterizing the relationships between soil organic matter components and microbial function and composition along a tillage disturbance gradient. Soil Biol Biochem. 2008, 40, 763-777. [CrossRef]

38. Li, T.; Sun, Z.; He, C.; Ge, X.; Ouyang, Z.; Wu, L. Changes in soil bacterial community structure and microbial function caused by straw retention in the North China Plain. Arch. Agron. Soil Sci. 2019. [CrossRef]

39. TerHeerdt, G.N.J.; Verweij, G.L.; Bekker, R.M.; Bakker, J.P. An improved method for seed-bank analysis: Seedling emergence after removing the soil by sieving. Funct. Ecol. 1996, 10, 144-151.

40. Gross, K.L. A comparison of methods for estimating seed number in the soil. J. Ecol. 1990, 78, 1079-1093. [CrossRef]

41. MacLaren, C.; Storkey, J.; Strauss, J.; Swanepoel, P.; Dehnen-Schmutz, K. Livestock in diverse cropping systems improve weed management and sustain yields whilst reducing inputs. J. Appl. Ecol. 2019, 56, 144-156. [CrossRef] 
42. Menalled, F.D.; Gross, K.L.; Hammond, M.; Menalled, F.D. Weed aboveground and seedbank community responses to agricultural management systems. Ecol. Appl. 2001, 11, 1586-1601. [CrossRef]

43. Ma, Z.; Ma, M.; Baskin, J.M.; Baskin, C.C.; Li, J.; Du, G. Responses of alpine meadow seed bank and vegetation to nine consecutive years of soil fertilization. Ecol. Eng. 2014, 70, 92-101. [CrossRef]

44. Ma, M.; Zhou, X.; Ma, Z.; Du, G. Composition of the soil seed bank and vegetation changes after wetland drying and soil salinization on the Tibetan Plateau. Ecol. Eng. 2012, 44, 18-24. [CrossRef]

45. Ma, M.; Zhou, X.; Wang, G.; Ma, Z.; Du, G. Seasonal dynamics in alpine meadow seed banks along an altitudinal gradient on the Tibetan Plateau. Plant Soil. 2010, 336, 291-302. [CrossRef]

46. Ortega, M.; Levassor, C.; Peco, B. Seasonal dynamics of Mediterranean pasture seed banks along environmental gradients. J. Biogeogr. 1997, 24, 177-195. [CrossRef]

47. San Martín, C.; Long, D.S.; Gourlie, J.A.; Barroso, J. Spring crops in three year rotations reduce weed pressure in winter wheat. Field Crop. Res. 2019, 233, 12-20. [CrossRef]

48. Nandan, R.; Singh, V.; Singh, S.S.; Kumar, V.; Hazra, K.K.; Nath, C.P.; Poonia, S.P.; Malik, R.K. Comparative assessment of the relative proportion of weed morphology, diversity, and growth under new generation tillage and crop establishment techniques in rice-based cropping systems. Crop Protect. 2018, 111, 23-32. [CrossRef]

49. Teasdale, J.R.; Mohler, C.L. Light transmittance, soil-temperature, and soil-moisture under residue of hairy vetch and rye. Agron. J. 1993, 85, 673-680. [CrossRef]

50. Case, M.J.; Stinson, K.A. Climate change impacts on the distribution of the allergenic plant, common ragweed (Ambrosia artemisiifolia) in the eastern United States. PLoS ONE 2018, 13, e0205677.

51. Sarrantonio, M.; Gallandt, E. The role of cover crops in North American cropping systems. J. Crop Prod. 2008, 8, 53-74. [CrossRef]

52. Lam, Y.; Sze, C.W.; Tong, Y.; Ng, T.B.; Tang, S.C.W.; Ho, J.C.M.; Xiang, Q.; Lin, X.; Zhang, Y. Research on the allelopathic potential of wheat. Agric. Sci. 2012, 03, 979-985. [CrossRef]

53. Wu, H.; Pratley, J.E.; Lemerle, D.; Haig, T. Allelopathy in wheat (Triticum aestivum). Ann Appl Biol. 2001, 139, 1-9. [CrossRef]

54. Ma, M.; Dalling, J.W.; Ma, Z.; Zhou, X. Soil environmental factors drive seed density across vegetation types on the Tibetan Plateau. Plant Soil. 2017, 419, 349-361. [CrossRef]

55. Mohler, C.L.; Asdale, J.R. Response of weed emergence to rate of Vicia villosa Roth and Secale cereale L. residue. Weed Res. 1993, 33, 487-499. [CrossRef]

56. Nichols, V.; Verhulst, N.; Cox, R.; Govaerts, B. Weed dynamics and conservation agriculture principles: A review. Field Crop. Res. 2015, 183, 56-68. [CrossRef]

57. Tetetla-Rangel, E.; Dupuy, J.M.; Hernández-Stefanoni, J.L.; Hoekstra, P.H. Patterns and correlates of plant diversity differ between common and rare species in a neotropical dry forest. Biodivers Conserv. 2017, 26, 1705-1721. [CrossRef]

58. Mulhouse, J.M.; Hallett, L.M.; Collins, S.L.; Vandvik, V. The influence of seasonal precipitation and grass competition on 20 years of forb dynamics in northern Chihuahuan Desert grassland. J. Veg. Sci. 2017, 28, 250-259. [CrossRef]

59. Jin, Y.; Li, J.; Liu, C.; Liu, Y.; Zhang, Y.; Song, Q.; Sha, L.; Chen, A.; Yang, D.; Li, P. Response of net primary productivity to precipitation exclusion in a savanna ecosystem. Ecol. Manag. 2018, 429, 69-76. [CrossRef]

60. Collins, D.B.G.; Bras, R.L. Plant rooting strategies in water-limited ecosystems. Water Resour Res. 2007, 43. [CrossRef]

61. Lindh, M.; Zhang, L.; Falster, D.; Franklin, O.; Brännström, Å. Plant diversity and drought: The role of deep roots. Ecol. Model. 2014, 290, 85-93. [CrossRef]

62. Mirsky, S.B.; Ryan, M.R.; Curran, W.S.; Teasdale, J.R.; Maul, J.; Spargo, J.T.; Moyer, J.; Grantham, A.M.; Weber, D.; Way, T.R.; et al. Conservation tillage issues: Cover crop-based organic rotational no-till grain production in the mid-Atlantic region, USA. Renew. Agric. Food Syst. 2012, 27, 31-40. [CrossRef]

63. Ryan, M.R.; Mirsky, S.B.; Mortensen, D.A.; Teasdale, J.R.; Curran, W.S. Potential Synergistic Effects of Cereal Rye Biomass and Soybean Planting Density on Weed Suppression. Weed Sci. 2011, 59, 238-246. [CrossRef]

64. Mikha, M.M.; Rice, C.W. Tillage and manure effects on soil and aggregate-associated carbon and nitrogen. Soil Sci. Soc. Am. J. 2004, 68, 809-816. [CrossRef]

65. Sainju, U.M.; Caesar-TonThat, T.; Jabro, J.D. Carbon and nitrogen fractions in dryland soil aggregates affected by long-term tillage and cropping sequence. Soil Sci. Soc. Am. J. 2008, 75, 1488-1495. [CrossRef]

66. Dikgwatlhe, S.B.; Chen, Z.D.; Lal, R.; Zhang, H.L.; Chen, F. Changes in soil organic carbon and nitrogen as affected by tillage and residue management under wheat-maize cropping system in the North China Plain. Soil Tillage Res. 2014, 144, 110-118. [CrossRef]

67. Zhang, S.; Chen, X.; Jia, S.; Liang, A.; Zhang, X.; Yang, X.; Wei, S.; Sun, B.; Huang, D.; Zhou, G. The potential mechanism of long-term conservation tillage effects on maize yield in the black soil of Northeast China. Soil Tillage Res. 2015, 154, 84-90. [CrossRef]

68. Powlson, D.S.; Stirling, C.M.; Jat, M.L.; Gerard, B.G.; Palm, C.A.; Sanchez, P.A.; Cassman, K.G. Limited potential of no-till agriculture for climate change mitigation. Nat. Clim. Chang. 2014, 4, 678-683. [CrossRef]

69. Xu, J.; Han, H.; Ning, T.; Li, Z.; Lal, R. Long-term effects of tillage and straw management on soil organic carbon, crop yield, and yield stability in a wheat-maize system. Field Crop. Res. 2019, 233, 33-40. [CrossRef]

70. Jordán, A.; Zavala, L.M.; Gil, J. Effects of mulching on soil physical properties and runoff under semi-arid conditions in southern Spain. Catena 2010, 81, 77-85. [CrossRef] 
71. Scopel, E.; Da Silva, F.A.M.; Corbeels, M.; Affholder, F.o.; Maraux, F. Modelling crop residue mulching effects on water use and production of maize under semi-arid and humid tropical conditions. Agronomie 2004, 24, 383-395. [CrossRef]

72. Gangwar, K.S.; Singh, K.K.; Sharma, S.K.; Tomar, O.K. Alternative tillage and crop residue management in wheat after rice in sandy loam soils of Indo-Gangetic plains. Soil Tillage Res. 2006, 88, 242-252. [CrossRef]

73. Ranaivoson, L.; Naudin, K.; Ripoche, A.; Affholder, F.; Rabeharisoa, L.; Corbeels, M. Agro-ecological functions of crop residues under conservation agriculture. A review. Agron. Sustain. Dev. 2017, 37, 1-7. [CrossRef] 